\title{
Oppdatert dobbeltdekker på lever-, galleveis- og pancreaskirurgi
}

ANMELDELSER

KJETIL SøREIDE

Honorary consultant surgeon, Royal Infirmary of Edinburgh

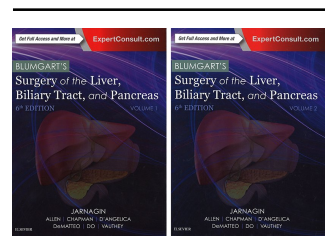

William R. Jarnaginred.

Blumgart's surgery of the liver, biliary tract and pancreas

2 bd. 6. utg. 2120 s, tab, ill. Philadelphia, PA: Elsevier, 2017. Pris EUR 379

ISBN 978-0-323-34062-5

Dette regnes som den klassiske læreboken innen lever-, galleveis- og pancreaskirurgi (HPBkirurgi), og denne sjette utgaven er den største og mest omfattende av samtlige. Målgruppen er erfarne kirurger så vel som utdanningskandidater, men også faggrupper i tilhørende disipliner, som radiologi. Redaksjonsmiljøet har sitt utgangspunkt i Memorial Sloan Kettering i New York, men det også er innslag fra andre tunge fagmiljøer i USA. Forfatterlisten for øvrig representerer de fleste kjente sentre i Europa, Asia og NordAmerika.

Disse to bindene dekker det meste av kunnskap innen anatomi og fysiologi, patologi og diagnose samt behandlingsaspekter av benigne og maligne tilstander i fagkomplekset. Både kirurgiske og ikke-operative behandlingsvalg diskuteres. Flere nye kapitler dekker molekylære mekanismer for kreftsvulster, temaer innen immunologi og innovative teknikker innen diagnostikk og behandling. Tekstene er rikt illustrert med til dels gjennomgående bruk av farger, med enkelte unntak hvor dette kunne vært gjort bedre. Rikelig bruk av illustrasjoner fra bildediagnostikk (ultralyd, CT eller MR) foreligger på tvers av tema.

Selv etter å ha fjernet samtlige referanser fra teksten i selve papirutgaven overskrider denne utgaven 2 ooo sider. Teksten er i hovedsak basert på oppdatert litteratur, men etter redaktørens ønske er tonen i kapitlene også sterkt basert på forfatternes egne synspunkter. Spesielt der litteraturen er svak eller mangelfull eller når det dreier seg om tilstander som er relativt sjeldne, er dette nyttig. Jeg savner imidlertid et tydeligere skille mellom hva som er litteraturbaserte og hva som er erfaringsbaserte meninger. Et redaksjonelt grep kunne 
vært å inkludere en tabellarisk oversikt over studier som styrer behandlingsvalg, for eksempel innen tumorrettet behandling.

I den elektroniske versjonen som følger med, får man tilgang til samtlige kapitler, og her er også referansene med. De er klikkbare slik at man kommer rett til hovedkilden på nett. Flere videoer på 5-10 minutter illustrerer konsepter innen anatomi og fysiologi samt åpne og laparoskopiske prosedyrer på lever, galleveier og pancreas. Den elektroniske versjonen har et positivt tillegg hvor man også kan gjøre egne notater i teksten, men dette krever internettilgang, noe som gjør nytteverdien mindre. Om dette fungerer bedre i den tilgjengelig Kindle-versjonen, er ikke vurdert.

Samlet sett er dette en lærebok som bør finnes på alle avdelinger der man driver med lever-, galleveis- og pancreaskirurgi. Sammen med løpende oppdatert litteratur er dette et nyttig kompendium, på tross av størrelse og pris.

Publisert: 8. januar 2018. Tidsskr Nor Legeforen. DOI: 10.4045/tidsskr.17.0865

(C) Tidsskrift for Den norske legeforening 2020. Lastet ned fra tidsskriftet.no 